Zofia Kaczmarek

(Poznań-Gniezno)

https://orcid.org/0000-0002-8478-7191

\title{
UBIÓR CZYNI RZYMIANINA? STYL ŻYCIA, FOLUSZNICY I ROMANIZACJA RZYMSKIEJ PROWINCJI PANONII (I-III WIEK N.E.)*
}

\begin{abstract}
The paper discusses the role of attire in the process of Romanization of Pannonia. Special emphasis is placed on the probability of clothes having been fulled in the province. Since fulling was a matter of personal interest, not necessity, the emergence of the fullonicae could be considered as a symptom of embracing Roman way of life and thus Roman culture.
\end{abstract}

\section{Key words}

fullers, dress, Roman Pannonia, Romanization

\section{WPROWADZENIE}

Omnibus autem Pannoniis non disciplinae tantummodo, sed linguae quoque notitia Romanae, plerisque etiam litterarum usus et familiaris animorum erat exercitatio ${ }^{1}$

Powyższe słowa, dotyczące Panonów żyjących w I wieku n.e., stały się zarzewiem dyskusji o poziomie romanizacji ludności zamieszkującej tereny na połu-

* Artykuł napisany w ramach projektu badawczego „Romanizacja obszarów zurbanizowanych w prowincjach reńsko-dunajskich Cesarstwa Rzymskiego (I-III w. n. e.)", finansowanego przez Narodowe Centrum Nauki (UMO-2015/19/B/HS3/00547).

1 Vel. Pat. II, 110,5. 
dnie od środkowego biegu Dunaju. Nie ulega wątpliwości, że słowa te odczytywać należy w kontekście całej historii rebelii przeciwko Rzymianom, o której mówi w tym fragmencie Paterkulus, jednak wielu historyków dołożyło starań, by ich dosłowne znaczenie uwiarygodnić2. Współcześnie badacze nie są tak optymistyczni i kwestionują nie tylko możliwość zweryfikowania poziomu romanizacji ${ }^{3}$, ale także i samo pojęcie. ${ }^{4}$ Chociaż w wyżej cytowanym tekście nie ma mowy o ubiorze, uważam głos Paterkulusa za dobry punkt wyjścia, ponieważ poprzez zwrócenie uwagi na przymioty ducha zarysowuje on dość szeroką perspektywę badań nad rolą kultury rzymskiej w Panonii.

Wydaje się, że dla Rzymian głównym dowodem rozprzestrzeniania się ich cywilizacji ${ }^{5}$ było przyjęcie przez lokalną ludność łaciny. Pisze o tym nie tylko Paterkulus, ale też Tacyt ${ }^{6}$. Warto podkreślić, że dla obu, mimo różnicy czasu, terytorium czy w końcu warunków życia w prowincji, jakie przyszło im opisywać, jest to element ważny, ale niewystarczający. Każdy z nich zdaje się podkreślać, że jest coś jeszcze, co ludność lokalną upodabnia do Rzymian. O ile pierwszy z autorów mówi o bliżej nieokreślonych cechach intelektu, których ćwiczenie przydaje Panonom rzymskości, o tyle drugi szczególną wagę przywiązuje do stylu życia ${ }^{7}$ - wymienia rozprzestrzenianie się zwyczaju korzystania z łaźni czy urządzania wykwintnych bankietów jako efekt wpływu rzymskiego ${ }^{8}$. Równie ważne okazuje się rozmiłowanie Brytów w rzymskiej modzie - Tacyt stwierdza, że na popularności zyskał zwyczaj noszenia togi ${ }^{9}$. W potocznym wyobrażeniu toga jest atrybutem Rzymianina, i niewątpliwie nim była, przynajmniej jako element kształtowania wizerunku, co potwierdzają liczne źródła ikonograficzne. Niemniej jednak u początków pryncypatu jej znaczenie w codziennym życiu publicznym musiało znacząco zmaleć, skoro August podjął specjalne kroki, by to zmienić ${ }^{10}$. Zapewne stąd też fragment „Eneidy”, w którym Wergiliusz charakteryzuje Rzymian jako „władców świata” (rerum domini) i „naród odziany w togi” (gens togata) ${ }^{11}$. Niezależnie jednak od jej faktycznej popularności, toga pozostała ubiorem ceremonialnym - symbolem

2 Por. Móscy 1983, s. 169-170, 175.

${ }^{3}$ Woolf 2001, s. 7.

${ }^{4}$ Webster 2001.

5 W opozycji do „barbarzyństwa” lokalnej ludności.

6 Tac. Agr. 21.

7 Styl życia rozumiem tutaj jako zespół codziennych (a więc nie wyjątkowych) rytuałów charakterystyczny dla danej jednostki lub zbiorowości, które odróżniają ją od innych (Siciński 2002, s. 22-23).

8 Tac. Agr. 21.

9 Ibidem („Inde etiam habitus nostri honor et frequens toga”).

10 Suet. Aug. 40.5, Stone 2001, s. 13.

${ }^{11}$ Ver. Aen. I, 282 (tłumaczenia Zygmunta Kubiaka). 
Rzymianina działającego w sferze publicznej ${ }^{12}$. Można więc powiedzieć, że według literackich przekazów vestis Romanum fecit nie mniej niż język czy styl życia.

Badania archeologiczne potwierdzają niektóre z pozostałych spostrzeżeń Tacyta - wraz z napływem do prowincji ludności z różnych obszarów Imperium, w tym samych Rzymian, krajobraz zaczął się zmieniać i kształtować na modłę rzymską. Pojawiły się miasta, różne od dotychczas znanych większych osad - oppidów. Ta nowa urbanizacja oznaczała rozprzestrzenienie elementów, które uznane zostały za charakterystycznie rzymskie: willi, forów, łaźni, świątyń, ale też i mozaik, malarstwa ściennego, nagrobków czy ceramiki. Powszechnie przyjmuje się, że to właśnie miasta stały się nośnikiem zmiany kulturowej ${ }^{13}$.

Miasta stwarzały okazję, by pokazać się publicznie. Wymagało to od ich mieszkańców, niezależnie od ich pochodzenia, dostosowania się do pewnych reguł w nich funkcjonujących. W związku z tym jednym $\mathrm{z}$ symptomów zmiany kulturowej, którą nieśli ze sobą Rzymianie, może być ubiór. Jako że jest powszechnie przyjęte, iż ubranie jest wyrazem tożsamości, wszelkie jego przeobrażenia mogą zostać uznane za formę akceptacji nowej kultury czy może raczej zaadaptowanie innego niż dotychczas stylu życia. Na temat ubiorów Rzymian i Panonów istnieje już bogata literatura ${ }^{14}$, dlatego skupię się na jednym detalu folowaniu tkanin. Moje rozważania ograniczam do stosunkowo wąskiego terytorium jednej prowincji - Panonii, mając nadzieję, że staną się one przyczynkiem do badań nad romanizacją ubioru tej prowincji. Obranie stosunkowo szerokiej perspektywy chronologicznej - wieki I-III n.e. - jest konieczne z kilku powodów. Sam sposób folowania, na tyle, na ile udaje się nam go dzisiaj odtworzyć, pozostawał niezmienny w omawianym okresie, nie da się więc na tej podstawie wydzielić podokresów ${ }^{15}$. Ponadto od przyłączenia Panonii do Cesarstwa Rzymskiego po okres panowania Sewerów prowincja stale rozwija się pod względem urbanizacyjnym, administracyjnym czy kulturowym. Źródła archeologiczne i historyczne potwierdzają, że gospodarka prowincji kwitła przez pierwsze trzy wieki panowania rzymskiego, i to pomimo wojen i rebelii, które co jakiś czas przetaczały się przez te tereny ${ }^{16}$. Wpływ rzymski staje się coraz bardziej uchwytny w różnych aspektach życia publicznego i prywatnego. Zatem tylko rozpatrzenie tej problematyki w tak szerokich ramach chronologicznych pozwoli na uchwycenie ewentualnych zmian.

12 Stone 2001, s. 13.

13 Laurence, Trifilò 2015, s. 103.

14 Np.: Grabsch 1965; Grabsch 1985; Sebsta i Bonfante 2001, Grömer 2014.

15 Ponadto od III wieku n.e. zaobserwować można pewną standaryzację jakości tkanin (Grömer 2014, s. 33).

16 Fitz 1980, s. 323. 
Folowanie jest jednym $\mathrm{z}$ ciekawszych procesów związanych z produkcją tekstylną w starożytnym Rzymie. Już sama nazwa może oznaczać dwie różne czynności: wykańczanie tkanin i pranie ich ${ }^{17}$. Pomimo że nie zachował się do naszych czasów żaden $\mathrm{z}$ antycznych opisów folowania ${ }^{18}$, dzięki źródłom archeologicznym i ikonograficznym jesteśmy dzisiaj w stanie zrekonstruować jego najważniejsze etapy.

Jednym z celów folowania było wykończenie tkaniny, przygotowanie jej do noszenia. $\mathrm{W}$ przeciwieństwie do średniowiecza $\mathrm{w}$ antycznym Rzymie nie było ono jednym $z$ kluczowych etapów produkcji włókienniczej ${ }^{19}$, traktowane było raczej jako zabieg dodatkowy o charakterze estetycznym ${ }^{20}$. Dzięki niemu bowiem ubrania zyskiwały wyjątkowy wygląd, białe nabierały blasku, kolorom zaś starano się przywrócić wyrazistość ${ }^{21}$. Co ciekawe, pomimo tych efektów folowanie niekoniecznie było luksusem dostępnym tylko elicie. Z czasów republikańskich znany jest wprawdzie plebiscyt lex Metilia de fullonibus, wymierzony przede wszystkim w senatorów ${ }^{22}$, ale z innych źródeł wyłania się obraz foluszy dostępnych dla większości społeczeństwa ${ }^{23}$.

Folusznicy rzymscy mieli do czynienia raczej z gotowymi ubraniami (vestis, vestimentum) $\mathrm{w}$ przeciwieństwie do ich średniowiecznych i nowożytnych kolegów, którzy zajmowali się przede wszystkim materiałami. Niestety, łacińscy autorzy nie precyzują, jaką odzież poddawano temu zabiegowi. Pewne wzmianki pojawiają się $\mathrm{w}$ tekstach pisanych greką ${ }^{24}$, najwięcej informacji przynosi dopiero Edykt Dioklecjana o cenach maksymalnych, źródło późne i kontrowersyjne. Niemniej potwierdza ono, że folusznicy mieli do czynienia głównie z płaszczami i tunikami ${ }^{25}$. Folowanie sprawiało, że odzież była bardziej komfortowa w noszeniu i cieplejsza. Wydawałoby się więc, że proces ten powinien stać się istotny w chłodnym klimacie, zwłaszcza na północy Europy. To, czy tkaniny będą folowane, zależało również od surowca, $z$ którego były wykonane. Zabiegowi temu poddawano głównie wełny $\mathrm{i}$ jedwabie, lny były gotowe do noszenia właściwie zaraz po ich utkaniu ${ }^{26}$. Warto też zwrócić uwagę, że żadne źródło nie mówi o folowaniu togi ${ }^{27}$.

17 Bradley 2002, s. 21.

18 Ibidem, s. 24-25.

19 Flohr 2013, s. 79-84; 2013a, s. 69.

${ }^{20}$ Idem 2013, s. 80-83; idem 2011, s. 209; Wild 1970, s. 83.

${ }^{21}$ Flohr 2013, s. 58-61.

${ }^{22}$ Ograniczał on tylko użycie glinki folarskiej (umbrica) przez foluszników (Plin. Nat. Hist. 35, 197, zob. także Bleicken 1965, s. 31-32).

${ }^{23}$ Flohr 2013, s.69.

${ }^{24}$ Ibidem, s. 62.

${ }^{25}$ Ed. Diocl. 22, Flohr 2013, s. 62.

${ }^{26}$ Flohr 2011, s. 209; Flohr 2013, s.62.

27 Idem 2013, s. 62. 
Drugim powodem, dla którego wyroby włókiennicze folowano, były względy higieniczne. W tym sensie folowanie oznaczało czyszczenie tkanin - usuwanie plam i innych zanieczyszczeń, wybielanie i odtłuszczanie. Oznacza to, że czynność ta była powtarzalna, a co za tym idzie - nie pozostawała bez wpływu na same tkaniny, które na skutek takiej obróbki wycierały się i szybciej zużywały ${ }^{28}$. Źródła literackie potwierdzają tę tezę, podkreślając, że wyroby włókiennicze często oddawane w ręce foluszników były warte mniej ${ }^{29}$. Wydaje się jednak, że nie miało to wpływu na popularność foluszy w rzymskiej Italii. Liczba tych warsztatów rzemieślniczych w italskich miastach (jak np. Rzym, Ostia, Herkulanum czy Pompeje) była znacząca, z czego można wnosić, że musiał istnieć popyt na ich usługi. Pozostaje więc pytanie, czy podobnie było w innych prowincjach Cesarstwa Rzymskiego.

\section{1. ŹRÓDłA DOTYCZĄCE FOLOWANIA W RZYMSKIEJ PANONII}

Na podstawie stosunkowo licznych źródeł archeologicznych stwierdzić można, że w Imperium Rzymskim istniały i funkcjonowały liczne folusze ${ }^{30}$. Jednakże liczba tych źródeł drastycznie spada, gdy ograniczyć obszar badań tylko do jednej prowincji. Panonia nigdy nie grała istotnej gospodarczej roli w Cesarstwie, zwłaszcza w produkcji tkackiej, a jej ekonomiczny rozwój zawsze zależał od armii, choć nie ona była wyłącznym odbiorcą panońskich produktów. Prowincja zamieszkana była przez różnorodną i wielokulturową ludność - zarówno lokalną, jak i napływołą, także z odległych części Cesarstwa - co oznacza, że założyć można istnienie rynku zbytu właściwie dla każdego przedmiotu czy usługi znanych w tym świecie.

W celu zweryfikowania hipotezy, według której usługi foluszników znajdowały popyt na terenie antycznej Panonii, należy wziąć pod uwagę trzy rodzaje źródeł: archeologiczne pozostałości foluszy (czyli budynki i infrastrukturę), materiał epigraficzny (inskrypcje wymieniające foluszników bądź ich kolegia) i tkaniny archeologiczne (zanalizowane pod kątem występowania na nich charakterystycznych cech folowania).

\subsection{Fullonicae}

Jednym z pierwszych badaczy, który zebrał i wyliczył cechy charakteryzujące folusze, był Mark Bradley ${ }^{31}$. Ich rozpoznanie w terenie pozwala na potwierdzenie, $\mathrm{z}$ dużą dozą prawdopodobieństwa, istnienie fullonica. Wśród tych cech wymienia

\footnotetext{
${ }^{28}$ Idem 2011, s. 209.

${ }^{29}$ Petron, Sat. 30, SHA, Heliogab. 26, por. Bradley 2002, s. 29-30.

${ }^{30}$ Flohr 2013, s. 12-35.

${ }^{31}$ Bradley 2002.
} 
takie jak stale, każda z miejscem na własną kadź, ale także ściany, na których wesprzeć się mogli ugniatający odzież, do tego duże, prostokątne zbiorniki służące namaczaniu i bieleniu tkanin. Niezwykle istotne dla funkcjonowania warsztatów foluszniczych są także dostęp do dużej ilości bieżącej wody czy istnienie kanałów odprowadzających tę zużytą. Ważnym źródłem są także pozostałości detergentów - glinki folarskiej, czy pozostałości naczyń, do których zbierano urynę. Najważniejsze jednak pozostają świadectwa epigraficzne ${ }^{32}$.

Poglądy Bradleya zostały ostro skrytykowane, przede wszystkim przez archeologów badających pozostałości foluszy w terenie ${ }^{33}$. Stwierdzili oni, że identyfikacja ich infrastruktury jest znacznie bardziej skomplikowana, szczególnie na tych stanowiskach, które długo były wystawione na działanie czynników atmosferycznych ${ }^{34}$, oraz na tych, które badane były w XIX i na początku XX wieku. Andrew Wilson zaproponował więc identyfikację tych warsztatów na podstawie mniej kontrowersyjnych przesłanek. Duże zbiorniki, które potrzebne były do namaczania tkanin, zwłaszcza jeśli zasilone zostały wodą doprowadzaną rurami z miejskiego akweduktu, mogą już służyć jako cecha diagnostyczna. Istnienie stali służących udeptywaniu jest równie istotne, niemniej pamiętać należy, że w północnych prowincjach mogły one być wykonane $\mathrm{z}$ drewna ${ }^{35}$ (prawdopodobnie taka konstrukcja przedstawiona jest na reliefie $\mathrm{z}$ francuskiego Sens ${ }^{36}$ ) i dlatego też mogły nie zachować się do naszych czasów lub zostać niezarejestrowane w czasie badań archeologicznych ${ }^{37}$. Z tych powodów identyfikacja foluszy w północnych prowincjach cesarstwa rzymskiego jawi się jako niezwykle trudne zadanie.

Już na początku II wieku n.e. większość panońskich miast posiadało infrastrukturę, która była niezbędna do funkcjonowania warsztatów foluszniczych, zwłaszcza stały dostęp do czystej wody doprowadzanej systemem rur z akweduktu bądź czerpanej ze studni lub publicznych fontann ${ }^{38}$. I tak dla przykładu, rozbudowanie sieci wodociągowej na terenie miasta cywilnego Aquincum miało miejsce prawdopodobnie za panowania Trajana ${ }^{39}$.

Nic więc dziwnego, że w tym mieście, które po 106 roku sprawowało funkcję stolicy Panonii Inferior, w trakcie XIX-wiecznych badań wykopaliskowych w budynku numer IX leżącym w jego południowo-wschodniej części dopatrzono się śladów funkcjonowania warsztatu foluszniczego, o czym pisze Klara Póczy w swo-

\footnotetext{
32 Ibidem, s. 26-27.

33 Flohr 2003, s. 447-450;Wilson 2003, s. 442-446.

34 Wilson 2003, s. 443.

35 Ibidem, s. 444.

36 Esparandieu 1911, 2768.

37 Wilson 2003, s. 444.

38 Droß-Krüpe 2016, s. 343; Wilson 2003, s. 444.

39 Láng 2016, s. 354; Póczy 2003, s. 145.
} 
im przewodniku po Aquincum ${ }^{40}$. Teza o istnieniu foluszu została jednak zweryfikowana w trakcie późniejszych analiz. Okazało się bowiem, że jedyną podstawą takiej identyfikacji funkcji tego budynku były baseny odkryte w północno-zachodnim narożniku domu ${ }^{41}$, co jest niewystarczającą przesłanką. Oznacza to, że warsztat foluszników w Aquincum prawdopodobnie nigdy nie istniał ${ }^{42}$, podobnie nie udało się go zidentyfikować wśród innych budynków odkrytych w trakcie badań archeologicznych na terenie całej prowincji ${ }^{43}$.

Nie oznacza to, że folusze w Panonii nie istniały. Stosunkowo niedawno, w czasie wykopalisk w południowej części przedmieścia Savarii, odkryto na tyle znaczącą liczbę narzędzi tkackich i ołowianych tabliczek, że założono istnienie pewnego rodzaju warsztatu rzemieślniczego związanego z produkcją tkacką, datowanego na koniec I początek II wieku n.e., prawdopodobnie związanego również z czyszczeniem tkanin. Fakt, że w pobliżu stanowiska przepływa strumyk (Perint), który nie tylko dostarczałby czystej wody, ale prawdopodobnie służyłby także do pozbywania się tej już zużytej, może stanowić dowód, że folowanie miało miejsce także w Savarii ${ }^{44}$.

Przemysł tkacki najlepiej rozwinął się w rzymskiej Siscii - w II wieku n.e. stała się ona jednym $z$ ważniejszych prowincjonalnych centrów obróbki wełny ${ }^{45}$, choć i tu nie udało się odnaleźć archeologicznych śladów folusza. Istnieją jednak inne dowody folowania tkanin, które zostaną omówione poniżej.

Jest rzeczą niezwykle intrygującą, że choć w samych Pompejach zidentyfikowano aż trzynaście foluszy, nie udało się potwierdzić istnienia żadnego w rzymskiej Panonii. Przyczyną takiego stanu rzeczy może być fakt, że model stosowany do identyfikacji tych warsztatów rzemieślniczych w prowincjach leżących w basenie morza Śródziemnego jest nieodpowiedni dla Północy Europy. Struktura czy wyposażenie „północnych” fullonicae mogły być inne niż tych w Rzymie czy np. w Ostii ${ }^{46}$. Jest wysoce prawdopodobne, że folusznicy w Panonii używali drewnianych naczyń i kadzi, które były dobrze znane w okresie poprzedzającym rzymski podbój $^{47}$.

Nie można także wykluczyć, że w omawianej prowincji działali folusznicy, którzy wędrowali od domu do domu, poszukując zatrudnienia na krótki okres czasu. Taka praktyka została opisana przez Warrona ${ }^{48}$, który twierdzi, że była ona niezwykle

40 Póczy 1969, s. 4.

${ }^{41}$ Zsidi 2006, s. 89.

42 Láng 2016, s. 358.

${ }^{43}$ Choć być może warsztaty takie istniały w Noricum (Gostenčnik 2014, s. 78-81).

${ }^{44}$ Kiss, Pásztókai-Szeőke i Weisz 2017, s. 90-91; Pásztókai-Szeőke i Radman-Livaja 2013, s. 55.

${ }^{45}$ Lolić 2003, s. 144.

${ }^{46}$ Gostenčnik 2013, s. 78; Gostenčnik 2014, s. 78.

47 Gostenčnik 2014, s. 78; idem 2013, s. 68; Wild 1970, s. 82; por. Leblanc 1996; Espérandieu $1911,2768$.

${ }^{48}$ Varro, Rust., I, XVI, 4, (por. 1-3). 
popularna na obszarach, które uważane były za niebezpieczne lub które znajdowały się blisko granic. Oznaczałoby to, że wszelkie zapotrzebowanie na pracę folusznika zaspakajane było w domostwach osób zainteresowanych i stąd nie było potrzeby tworzenia osobnych warsztatów. Taka praktyka wędrownych foluszników raczej nie obejmowała miast, służyła bardziej prywatnym właścicielom willi.

\subsection{Epigrafika}

Najliczniejszą kategorią źródeł epigraficznych dotyczących foluszników i ich pracy jest zbiór ołowianych tabliczek z miasta Siscia ${ }^{49}$. Są to prostokątne plakietki, długie na około 30-40 $\mathrm{mm}$ i szerokie na $15-25 \mathrm{~mm}$, zawsze przynajmniej z jedną dziurką w rogu, która umożliwiała ich przytwierdzenie do jakiegoś przedmiotu przy pomocy drucika lub sznurka. Ponadto każda z nich ma inskrypcję na przynajmniej jednej, ale najczęściej na obu stronach. Zwykle na jednej z nich wyryte są imiona, nie tylko praenomina, ale także duo nomina czy (rzadko) tria nomina ${ }^{50}$, często $\mathrm{w}$ różnych przypadkach (nominatiwie, genetiwie czy datiwie) ${ }^{51}$. Warto też zauważyć, że są to imiona nie tylko rzymskie, ale i lokalne ${ }^{52}$. Na drugiej stronie tabliczek treść jest różnorodna, ale zwykle jest to nazwa produktu (często w skróconej formie), czasami podana jest waga, ilość, cena czy nawet czynność, jaka ma zostać wykonana. Badania wykazują także, że ołowiane tabliczki są palimpsestami. Wydaje się, że były one przeznaczone do przytwierdzania ich do tkanin pozostawionych u folusznika czy farbiarza, ponieważ to nazwy odzieży dominują $\mathrm{w}$ inskrypcjach ${ }^{53}$. Ponadto o ich wykorzystaniu w foluszach świadczyć mogą skróty F, FUL, FULLO ${ }^{54}$.

Największa kolekcja z Sisci nie jest jedynym zbiorem ołowianych tabliczek. Większość z nich została co prawda znaleziona w innych prowincjach (w Noricum i w Germaniach), ale i w Panonii wymienić należy przynajmniej ${ }^{55}$ trzy stanowiska, na których je odkryto. Pierwsze z nich to Carnuntum, gdzie znaleziono co najmniej jedną z wyrytą na niej nazwą tkaniny ${ }^{56}$, drugie to Savaria ${ }^{57} \mathrm{i}$ trzecie, choć nie można z całą pewnością stwierdzić, do czego dokładnie te tabliczki były używane,

\footnotetext{
${ }^{49}$ Koščevic 2013, s. 21-22; Radman-Livaja 2013, s. 89, 94; Idem 2011, s. 181.

${ }^{50}$ Czyje to są imiona, pozostaje dyskusyjne. Radman-Livaja 2014, s. 118-121; idem 2013, s. 94 104; idem 2011, s. 191-194.

${ }^{51}$ Idem 2013, s. 90; idem 2011, s. 181-182.

${ }^{52}$ Idem 2011, s. 182, 184.

${ }^{53}$ Idem 2013, s. 98-100; idem 2011, s. 181.

${ }^{54}$ Trzeba jednak przyznać, że interpretacja tych skrótów jest problematyczna (idem 2014, s. 79-80).

55 Ibidem, s. 50-51.

${ }^{56}$ Römer-Martijnse 1987, s. 119-122.

${ }^{57}$ Pásztókai-Szeöke 2014, s. 7.
} 
to Ribnica ${ }^{58}$. Wszyscy jednak autorzy publikacji tych tabliczek podkreślają prawdopodobieństwo ich użycia w przemyśle tekstylnym ${ }^{59}$.

Nie znam inskrypcji kamiennej wspominającej foluszników w Panonii. Oczywiście założyć można, że znaczenie czy zarobki tej grupy zawodowej nie pozwoliły na realizację takich inwestycji. Argument ex silentio nie powinien jednakże być tutaj przesądzający. Liczba ołowianych tabliczek pozwala na wyciągnięcie wniosku, że przemysł tkacki, $w$ tym i prawdopodobnie folowanie tkanin, znajdował popyt wśród mieszkańców prowincji. Pozostaje mieć nadzieję, że nowe badania (np. te nad warsztatem włókienniczym w Savarii ${ }^{60}$ ) przyniosą konkretniejsze wiadomości na temat działalności foluszników w Panonii.

\subsection{Tkaniny archeologiczne}

Tkaniny wykopaliskowe, choć dzięki coraz to nowocześniejszej metodyce badań ich ilość stale się powiększa, nadal uważane są za niezwykle rzadkie źródło archeologiczne. W dobrym stanie przetrwać mogą jedynie w sprzyjających warunkach takich, jak pustynie czy bagna ${ }^{61}$. Klimat Europy Centralnej, z jego zmieniającymi się porami roku, nie sprzyja zachowywaniu się tkanin ${ }^{62}$. Większość z nich znajdowana jest w bliskim sąsiedztwie metali, głównie przedmiotów brązowych, których tlenki mają dobroczynny wpływ na konserwację włókien. Tkaniny, które w taki sposób przetrwały do naszych czasów, są jednak małe, silnie zniekształcone i brązowawe w kolorze. Mimo to udało się do tej pory zebrać w miarę reprezentatywną kolekcję tych źródeł ${ }^{63}$, która umożliwia, na bazie metod statystycznych, wyciągnięcie pewnych wniosków.

Dodatkową trudnością w badaniach nad antycznym włókiennictwem jest fakt, że dopiero niedawno udało się badaczom tekstyliów wypracować metodologiczne podstawy analizy tej kategorii źródeł. Jeszcze pod koniec XX wieku część tkanin wykopaliskowych była źle lub niezrozumiale opracowywana, ale przede wszystkim nie była poddawana, uważanym obecnie za standardowe, ekspertyzom ${ }^{64}$. Wyciągnięciu bardziej ogólnych wniosków dotyczących produkcji tkackiej na danym terytorium nie sprzyja też fakt, że część analiz publikowana jest w językach narodowych i nieprezentowana na międzynarodowych forach.

\footnotetext{
58 Lovenjak 2005, s. 43.

59 Zob. także Mócsy 1956, s. 103-104.

60 Pásztókai-Szeőke i Radman-Livaja 2013.

61 Wild 1988, s. 7; Schlabow 1976, s. 11-12; Wild 1970, s. 41.

62 Wild 1970, s. 41.

63 Ibidem.

64 Bender-Jørgensen 1993, s. 109.
} 
Z panońskiej części dzisiejszej Austrii znane są zaledwie 184 tekstylia, znalezione $\mathrm{w}$ różnych kontekstach, najczęściej w grobach $^{65}$. Ponad 150 wyrobów włókienniczych z okresu rzymskiego z terytorium dzisiejszych Węgier zostało przebadanych w ramach projektu DressID, jednak wyniki do dziś nie zostały opublikowane $^{66}$. Co prawda istnieją publikacje $\mathrm{z}$ badań pojedynczych znalezisk ${ }^{67}$, ale na żadnej $\mathrm{z}$ tych tkanin nie znaleziono pewnych śladów folowania. Są one bardzo charakterystyczne - dają zamkniętą powierzchnię tkaniny pokrytą kutnerem, przez co nie widać nici wątku i osnowy ${ }^{68}$.

Nie oznacza to, że w ogóle nie znamy tkanin folowanych znalezionych na obszarach północnych prowincji Cesarstwa Rzymskiego. Poddana temu zabiegowi została prawdopodobnie tkanina z Verulamium (prowincja Brytania, dzisiejsze St Albans w Hrabstwie Hertfordshire w Anglii) w splocie rombowym, na której kutner, utrudniający analizę splotu, jest zdecydowanie widoczny ${ }^{69}$.

Tkaniny archeologiczne z okresu rzymskiego z Panonii są nieliczne, stosunkowo niewielkie i w większej części silnie zmineralizowane, ze względu na fakt przylegania do przedmiotów metalowych ${ }^{70} . \mathrm{Z}$ tego powodu nie mogą stanowić rozstrzygającego dowodu w kwestii popularności folowania. Jednakże na ich podstawie stwierdzić można stały rozwój umiejętności włókienniczych na terenie Panonii i stosowanie technologii nieodbiegającej od tej z pozostałych obszarów Imperium Rzymskiego ${ }^{71}$.

\section{UBIÓR A ROMANIZACJA}

Ubiór może być uważany za wyraz tożsamości. Może być manifestacją etniczności, religii, płci kulturowej czy samej kultury, z której się wywodzimy, staje się więc wizualnym komunikatem dla innych. Aby komunikat ten został zrozumiany, musi być odczytywany według właściwego dla niego kontekstu geograficznego i chronologicznego ${ }^{72}$. W sztuce rzymskiej zasada ta jest szczególnie widoczna ubrane ciało wystarcza, by określić płeć, wiek czy status ${ }^{73}$.

Co więcej, różnice w ubiorze stają się cechą charakterystyczną poszczególnych grup, do których przypisuje się osoby, które poprzez specyficzny dress code

65 Grömer 2014, s. 25.

66 Ibidem, s. 35.

67 Hajnal 1965, s. 259-266; por. Barkóczi 1965, s. 251; Grömer 2014, s 35.

68 Maik 2012, s. 87.

69 Wild 1970, s. 84. Splot rombowy z Verulamium nie jest jednak jedynym dowodem, że folowanie tkanin w rzymskiej Brytanii było popularne (Wild 1967).

70 Grömer 2014, s. 25.

71 Ibidem, s. 33-35; 57-81.

72 Sommer 2012, s. 257.

73 Larson Lovén 2014, s. 267-268; Carroll 2013, s. 567-568. 
z nimi się utożsamiają. Ubiór nie tylko więc tworzy tożsamość zbiorową danego środowiska, ale także jest wyrazem przynależności do niego. Badania pokazują, że ludzie o podobnych warunkach życia, źródłach wiedzy czy wartościach rozwijają podobny styl i gust, co dotyczy także odzieży ${ }^{74}$. Jej wybór nigdy więc nie będzie przypadkowy - staje się wyrazem dostosowania się lub niedostosowania się do obowiązujących trendów czy czasów. Takie rozumienie ubioru pozwala na wyciągnięcie wniosków również w kontekście romanizacji.

Koncepcja romanizacji, w znaczeniu akulturacji, czyli przejmowania bezkrytycznie i w całości rzymskich wzorców kulturowych, doczekała się wielu głosów krytycznych. Nie ma tu jednak miejsca, by przytaczać wszystkie zarzuty, przedstawiono je $\mathrm{z}$ resztą $\mathrm{w}$ licznych publikacjach ${ }^{75}$, proponując nawet wyrzucenie terminu „romanizacja” ze słownika badań historycznych ${ }^{76}$.

Zdając sobie sprawę z faktu, że w po zwrocie postkolonialnym w humanistyce termin ten w znaczeniu, jakie jemu nadali Theodor Mommsen i Francis J. Haverfield, musi ulec reinterpretacji, uważam jednak, iż negacja opisywanego przezeń zjawiska, tudzież stosowanie nowej terminologii, nie tylko wprowadzi niepotrzebny chaos w dotychczasowych badaniach, ale także nie wytrzyma krytyki w zestawieniu $\mathrm{z}$ faktami ${ }^{77}$. Wszak wszyscy badacze, niezależnie od ich poglądów na temat romanizacji, właściwie zgadzają się w jednym - zajmowanie przez Rzymian nowych terenów zawsze pociągło za sobą Zmianę.

Zmianę tę zaobserwować można również w stylu ubierania się ludności lokalnej. W nauce istnieją dwa sprzeczne poglądy dotyczące romanizacji odzieży. Pierwszy zakłada, że „globalizacja” kultury materialnej, która nastąpiła wraz z rzymskim podbojem, nie dotknęła tekstyliów. Świadectwem jest edykt Dioklecjana o cenach maksymalnych, w którym niektóre sztuki odzieży, np. byrros, charakteryzowane są przez nazwy regionów geograficznych, z których pochodzą (np. brytyjski, norycki itp. ${ }^{78}$ ). Daje to podstawę do wysunięcia tezy, że strój regionalny, pomimo pewnej standaryzacji konsumpcji w Imperium, przetrwał nawet do początków IV wieku n.e. Z drugiej jednak strony jego wymienienie w edykcie wskazuje, że był on dostępny na większym terytorium, przynajmniej na tym, na którym rozkaz cesarski obowiązywał ${ }^{79}$.

Drugi pogląd opiera się na wspomnianym już fragmencie Agrykoli Tacyta ${ }^{80}$, który to wyraźnie stwierdza, że w prowincjach, a przynajmniej w Brytanii, popu-

\footnotetext{
74 Sommer 2012, s. 258-259.

75 Np. Mrozewicz 2017, Webster 2001, Woolf 1998, Milett 1990.

76 Webster 2001.

77 Mrozewicz 2017, s. 284-285.

78 Ed. Dioclet. 19.1.44-55.

79 Flohr 2014, s. 3.

80 Tac. Agr. 21.
} 
larna stała się toga. Jest to wyraźny sygnał pewnej standaryzacji ubierania się, jak również przejmowania rzymskiego stylu, akceptacji trendów niejako narzuconych przez najeźdźcę. Pośrednio zaś świadczy o tym, że ludność lokalna przejęła styl życia i przynajmniej pewne wartości od Rzymian.

W tym kontekście ciekawy staje się fakt, że większosśc informacji dotyczących Panonów pochodzi z połowy, a nawet z późnego I wieku n.e. Nie ma dowodów na wspólną tożsamość mieszkańców prowincji przed rzymskim podbojem ${ }^{81}$. Wraz z nim pojawia się też zwyczaj wystawiania nagrobków, dzięki czemu mamy więcej informacji dotyczących stroju lokalnej ludności ${ }^{82}$. I tak dla przykładu, z tych terenów znane są stele kamienne, na których przedstawiono zmarłych o lokalnych imionach, ale ubranych na modłę rzymską ${ }^{83}$, choć oczywiście nie brakuje też wizerunków mężczyzn noszących strój lokalny ${ }^{84}$. Zdecydowanie więcej można powiedzieć o strojach kobiecych. Analiza ikonografii sepulkralnej potwierdziła istnienie specyficznego, norycko-panońskiego ubioru, charakteryzującego się przede wszystkim spiętym na ramionach przy pomocy fibul fartuchem i nakryciem głowy przypominającym turban. Znany on był jeszcze przed rzymskim podbojem, rekonstruowano go na podstawie wyposażenia grobowego ${ }^{85}$. Jednakże nawet tak bogaty materiał źródłowy nie daje pełnej informacji na temat mody w prowincji, czyli o tym, co, jak często i przy jakiej okazji noszono ${ }^{86}$. Niemniej, skoro wizerunki nagrobne są świadectwem tego, jak chciano, by zmarły był zapamiętany po śmierci, stają się wymownym dowodem, że chciał on (lub jego bliscy) być uznany za część konkretnej, nie zawsze rzymskiej, społeczności.

Niestety na podstawie źródeł ikonograficznych nie można stwierdzić, czy ubrania na nich przedstawione folowano. Wyłania się jednak z nich obraz mieszkańców prowincji, którzy byli świadomi swojego celtyckiego dziedzictwa, a jednocześnie chętnie przyjmowali nowinki ze świata najeźdźców (same kamienne nagrobki nie były znane przed rzymskim podbojem ${ }^{87}$ ). Ponadto liczne przedstawienia płaszczy i tunik, ubiorów najchętniej oddawanych folusznikom, pozwalają przypuszczać, że istniało pewne zapotrzebowanie na ich usługi.

81 Dzino i Kunić 2012, s. 100.

82 Grabsch 1985, s. 548.

83 Np. Schober 1923, s. 86 (CIL III 4276); Schober 1923, s. 118 (CIL III 15154); RIU 3:911; Maróti 2003, il. 31.6.

${ }^{84}$ Grabsch 1985, s. 574-575.

85 Ibidem, s. 554-555; Fitz 1980a, s. 142; Mócsy 1974, s. 149-150; por. Grabsch 1965. Pierwsze zmiany odnotować można dopiero w II wieku n.e. - fibule stają się coraz rzadszym elementem stroju (Grabsch 1985, s. 558, 576).

86 Pásztókai-Szeöke 2014, s. 6.

87 Dzino\&Kunić 2012, s. 103. 


\section{PODSUMOWANIE}

Panonia jako prowincja stała się rynkiem właściwie dla każdej usługi, jaką mogło zaoferować Imperium Rzymskie, nie wyłączając włókiennictwa. Brak różnorodnych źródeł potwierdzających istnienie profesji foluszników na terenie prowincji jest niewątpliwie problematyczny, choć może wynikać ze stanu badań ${ }^{88}$. Nowe analizy, zarówno ołowianych tabliczek, jak i warsztatu włókienniczego w Savarii, pokazują, że na przełomie I i II wieku n.e. istniała złożona, zorientowana na klienta usługa związana z produkcją tkacką ${ }^{89}$. Korzystać z niej mogły zarówno osoby pochodzenia rzymskiego, jak i ludność lokalna, o czym świadczą imiona podane na tabliczkach. Ponadto fakt, że źródła te są pisane łaciną, dowodzi, że pracujący w tym warsztacie znali przynajmniej podstawowe słownictwo i posługiwali się nim $\mathrm{w}$ kontaktach $\mathrm{z}$ klientami ${ }^{90}$, ale też silnie wiąże te usługi $\mathrm{z}$ rzymskim stylem życia. W ten sposób słowa Welejusza Paterkulusa i Tacyta o znaczeniu łaciny jako pewnego dowodu na rozprzestrzenianie się romanitas znajdują tu potwierdzenie.

Głównym zadaniem foluszników było nadanie tkaninie splendoru, sprawienie, by lepiej się prezentowała ${ }^{91}$. Usługa ta więc nie była skierowana $\mathrm{w}$ jednakowym stopniu do wszystkich członków rzymskiej społeczności, a głównie do tych, którzy chcieli podkreślić swoje bogactwo, ekskluzywność stylu życia czy wyższość pochodzenia ${ }^{92}$. Niektóre egipskie papirusy podają również niskie kwoty za pojedyncze transakcje ${ }^{93}$, oznacza to, że wprawdzie folowanie było dostępne dla wszystkich członków prowincjonalnego społeczeństwa, jednak elity odwiedzały folusze częściej ${ }^{94}$. Tę tezę może potwierdzać też geograficzna dystrybucja tych warsztatów - największa ich liczba odkryta została w Italii, w większych i bogatszych miastach, w pobliżu Rzymu, których mieszkańcy mogli mieć więcej okazji (lub konieczności), by chwalić się swym ubiorem, dlatego też potrzebowali folowania częściej ${ }^{95}$. Niemniej przytoczone wyżej świadectwa pozwalają przypuszczać, że i w Panonii istniała grupa ludności gotowa skorzystać z usług włókienniczych wedle rzymskiej mody.

${ }^{88}$ Dla przykładu w sąsiednim Noricum udało się, choć również nie bez wątpliwości, zidentyfikować jeden warsztat foluszniczy (Grömer 2014, s. 80-81).

${ }^{89}$ Pásztókai-Szeöke 2014, s. 9-10.

90 Ibidem, s. 14.

${ }^{91}$ Wbrew powszechnej opinii nie oznacza to wybielania tkaniny - najlepszym przykładem jest tutaj toga candida, która nigdy nie jest opisywana jako alba (Flohr 2013, s. 59-60), chociaż S. Stone uważa, że candida oznacza sztucznie bieloną, w przeciwieństwie do toga pura, która miała być naturalnego koloru wełny (Stone 2001, s. 15).

92 Flohr 2013, s. 67.

93 Por. ibidem, s. 69, Radman-Livaja 2014, s, 98.

94 Flohr 2013, s. 69-70.

${ }^{95}$ Ibidem, s. 70-72. 
Odpowiedzieć by zatem należało na tytułowe pytanie, czy ubiór czyni Rzymianina. Z dostępnych nam źródeł wyłania się odpowiedź niejednoznaczna. Panońskie nagrobki $\mathrm{z}$ wizerunkami zmarłych, głownie kobiet, w lokalnym, norycko-panońskim stroju są świadectwem wciąż silnej celtyckiej tożsamości. Jednakże obok nich istnieją nagrobki lokalnej ludności, głównie mężczyzn, ubranych według rzymskiej mody. Taki wizerunek może być odczytywany jako symbol przyjętych w prowincji ról społecznych. Aktywność kobiet ograniczona była do strefy domowej, predestynując je niejako do roli przekazicielek tradycji. Mężczyźni zaś działali w sferze publicznej ${ }^{96}$, której ton nadawali Rzymianie, stąd oni pierwsi dostosowywali się do nowej sytuacji, dając temu wyraz swoim ubiorem. Równie istotne jest istnienie wspomnianej wyżej grupy ludności (elity?), także lokalnej, gotowej korzystać z usług warsztatów włókienniczych w Siscii czy Savarii. Często przedstawiane w ikonografii sepulkralnej tuniki i płaszcze, które były tak popularne na obszarze całego Imperium, mogą być świadectwem akceptacji rzymskiej mody.

Czy przyjęcie rzymskiego stroju było równoznaczne z przyjęciem rzymskiego stylu życia, codziennych rytuałów - zachowań wraz z ich motywacjami i znaczeniem? ${ }^{97}$ Postawieni w sytuacji wyboru, mieszkańcy prowincji decydowali się wyrażać swoją tożsamość poprzez kulturę najeźdźców - używali języka łacińskiego, by zapisywać swoje imiona, wystawiali nagrobki czy osiadając w miastach, korzystali z dorobku rzymskiej cywilizacji: akweduktów, dróg, ale i łaźni czy w końcu usług rzemieślniczych, nawet jeśli nie foluszników, to z pewnością innych, również związanych z produkcją tkacką. Tak więc Rzymianina czynił nie sam ubiór, ale cały system zachowań i posługiwania się znakami uniwersalnymi dla rzymskiego świata.

Pozornie paradoksalny wydaje się fakt, że dopiero po rzymskim podboju dowiadujemy się o istnieniu tożsamości panońskiej. Wcześniej wszakże prowincję tę zamieszkiwały różne ludy, które miały swoją własną, odrębną od innych, nawet sąsiadów, tożsamość. Dopiero rzymski podbój i nadanie temu terytorium spójnego administracyjnie i kulturalnie charakteru umożliwiło uformowanie się jednej grupy ludności, dla której punktem odniesienia stała się prowincja jako część wielkiego Imperium. Podkreślić zatem należy rolę Rzymu jako łącznika różnych tożsamości, a jego kulturę - wraz z językiem i stylem życia - nazwać można czynnikiem integrującym, który pozwolił przetrwać Cesarstwu na tak różnorodnych terytoriach przez przynajmniej kilka stuleci.

\footnotetext{
${ }^{96}$ Carroll 2013, s. 571-572.

${ }^{97}$ Siciński 2002, s. 22-23.
} 


\section{THE DRESS MAKES THE ROMAN? LIFESTYLE, FULLERS AND THE ROMANIZATION OF PANNONIA ( $1^{\text {ST }}-3^{\text {RD }}$ CENTURY CE)}

\section{Summary}

The fulling of clothes was one of the finishing processes of textile production, but it was not a necessity. It made clothes more comfortable to wear and warmer, but more importantly it gave garments a lustre, a more elegant look and, therefore, it was closely linked in the Roman period with cultural and personal notions of style and good taste.

The fullonicae, although best known from Pompeii in Italy, are also believed to have existed be in some of the urban centres in the Roman provinces on the Danube, though their identification has given rise to some controversy. Nevertheless, archaeological remnants of fulleries are not the only type of source to help us study Roman fulling, as there are also epigraphy or textile remains.

Despite the fact that there are no unequivocal sources to confirm the presence of fullers in Roman Pannonia, one can be certain of the existence of a complex, client-oriented textile service at the turn of the second century CE. I believe that since it is a common paradigm that clothing express one's identity, the choice of clothes can serve as one of the indicators of Romanization. Careful analysis of textile-related sources shows that the inhabitants of Pannonia, although faithful to their local traditions, remained open-minded to the novelties of Roman civilization. Roman lifestyle became a factor integrating the various territories which made up the vast Empire.

\section{Bibliografia}

Barkóczi L. 1965, New Data on the History of Late Roman Brigetio, Acta Antiqua Academiae Scientiarum Hungaricae, 13, s. 215-257.

Bender Jørgensen L. 1993, North European Textiles until AD 1000, Aarhus.

Bleicken J. 1955, Das Volkstribunat der Klassischen Republik. Studien zu seiner Entwicklung zwischen 287 und 133 v. Chr, München.

Bradley M. 2002, It all comes out in the wash: Looking Harder at the Roman fullonica, Journal of Roman Archaeology 15, s. 20-44.

Carroll M. 2013, Ethnicity and Gender in Roman Funerary Commemoration. Case studies from the Empire's Frontiers, [w:] S. Tarlow, L. Nilsson Stutz (red.), The Oxford Handbook of the Archaeology of Death and Burial, Oxford, s. 559-579.

Dzino D. i Kunić A.D. 2012, Pannonians: Identity-Perceptions from the Late Iron Age to Later Antiquity, [w:] B. Migotti (red.), The Archaeology of Roman Southern Pannonia. The State of Research and Selected Problems in the Croatian Part of the Roman Province Pannonia, Oxford, s. 93-115.

Droß-Krüpe K. 2016, Spatial Concentration of Roman Textile Crafts, [w:] A. Wilson, M. Flohr (red.), Urban Craftsmen and Traders in the Roman World, Oxford, s. 334-351.

Espérandieu E. 1911, Recueil général des bas-reliefs, status et bustes de la Gaule Romaine, IV, Paris.

Fitz J. 1980, Economic life, [w:] A. Lengyel, G.T.B. Radan (red.), The Archaeology of Roman Pannonia, Budapest, s. 323-335.

Fitz J. 1980a, Population, [w:] A. Lengyel, G.T.B. Radan (red.), The Archaeology of Roman Pannonia, Budapest. 
Flohr M. 2003, Fullones and Roman Society: a Reconsideration, Journal of Roman Archaeology 16, s. $447-450$.

Flohr M. 2011, Consumption, not production. Understanding the fullonicae of Pompeii, [w:] C. Alfaro, J.P. Brun, R. Pierobon Benoit, Ph. Borgard (red.), Purpurae Vestes. III Symposium Internacional sobre Textiles y Tintes del Mediterráneo en el mundo antiguo, València, s. 209-215.

Flohr M. 2013, The World of the Fullo. Work, Economy, and Society in Roman Italy, Oxford.

Flohr M. 2013a, The textile economy of Pompeii, Journal of Roman Studies 26, s. 53-78.

Flohr M. 2014, Towards an Economic History of Textile Manufacturing and Trade in the Roman World, [w:] K. Droß-Kürpe (red.), Textile Trade and Distribution in Antiquity, Wiesbaden, s. 1-16.

Gostenčnik K. 2013, Textile Production and Trade in Roman Noricum, [w:] M. Gleba, J. Pásztókai-Szeőke (red.), Making Textiles in Pre-Roman and Roman Times. People, Places, Identities, Oxford, s. 60-86.

Gostenčnik K. 2014, Textilproduktion in der Austria Romana, [w:] K. Grömer, Römische Textilien in Noricum und Westpannonien im Kontext der archäologischen Gewebefunde 2000 v. Chr. 500 n. Chr. In Österreich, Graz, s. 57-109.

Grabsch J. 1965, Die Norisch-Pannonisch Frauentracht im 1. und 2. Jahrhundert, München.

Grabsch J. 1985, Die norisch-pannonische Tracht, Aufstieg und Niedergang der Römischen Welt 12.3, s. 546-577.

Grömer K. 2014, Römische Textilien in Noricum und Westpannonien im Kontext der archäologischen Gewebefunde 2000 v. Chr. - 500 n. Chr. In Österreich, Graz.

Hajnal L. 1965, Textiles from the Graves of Late Roman Brigetio, Acta Antiqua Academiae Scientiarum Hungaricae, 13, s. 259-266.

Kiss V., Pásztókai-Szeőke J. i Weisz B. 2017, Mixtura Texturalis. People and Textiles in the Carpathian Basin, Archaeological Textiles Review 59, s. 90-91.

Koščević R. 2013, Siscia, Pannonia Superior, Old and new finds, Oxford.

Láng O. 2016, Industry and Commerce in the City of Aquincum, [w:] A. Wilson, M. Flohr (red.), Urban Craftsmen and Traders in the Roman World, Oxford, s. 352-377.

Larsson Lovén L. 2014, Roman Art: What Can It tell Us About Dress and Textiles? A Discussion on the Use of Visual Evidence as Sources for Textile Research, [w:] M. Harlow, M.-L. Nosch (red.), Greek and Roman Textiles and Dress: an Interdisciplinary Anthology, Oxford.

Laurence R. i Trifiò F. 2015, The Global and the Local in the Roman Empire: Connectivity and Mobility from an Urban Perspective, M. Pitts, M.J. Versluys (red.) Globalisation and the Roman World, World History, Connectivity and Material Culture, Cambridge, s. 99-122.

Leblanc O. 1996, Les basins des foulons sur le site de Sain-Romain-en-Gaule (Rhône), [w:] Aspects de l'artisanat du textile dans le monde méditeranéen (Egypte, Grèce, Monde romain), Paris, s. $137-142$.

Lolić T. 2003, Colonia Flavia Siscia, [w:] M. Šašel Kos, P. Scherrer (red.), The Autonomous Towns of Noricum and Pannonia/Die Autonomen Städte in Noricum und Pannonien, Ljubljana, s. 131-152.

Lovenjak M. 2005, Roman Lead Tablet from Ribnica with an Inscription in Cursive Writing, Instrumentum, 21, s. 42-43.

Maik J. 2012, Włókiennictwo kultury wielbarskiej, Łódź.

Maróti É. 2003, Die römischen Steindenkmäler von Szentendre - Ulcisia Castra Austellungskataloge 4. Pest Megyei Múzeumok Igazgatósága, Szentendre.

Millett M. 1990, The Romanization of Britain, Cambridge. 
Mócsy A. 1956, Ólom árucímkék Sisciából, Folia Archaeologica, 8, s. 97-104.

Mócsy A. 1974, Pannonia and Upper Moesia. A History of the Middle Danube Provinces of the Roman Empire, London.

Mócsy A. 1983, The Civilized Pannonians of Velleius, [w:] B. Hartley, J. Wacher (red.), Rome and her Northern Provinces. Papers presented to Sheppard Frere in honour of his Retirement from the Chair of the Archaeology of the Roman Empire, University of Oxford, 1983, Gloucester, s. $169-176$.

Mrozewicz L. 2017, Romanisierung als Integrationsfaktor des Imperium Romanum, Studia Europaea Gnesnensia 16, s. 281-293.

Pásztókai-Szeőke J. 2014, A római toga viselése Pannoniában- egy mítosz és a valóság, Korall, 55, s. 5-22.

Pásztókai-Szeőke J. i Radman-Livaja I. 2013, Textilmühely az Iseum területén, [w:] O. Sosztarits, P. Balázs i A. Csapláros (red.) A savariai Isis szentély. Sistrum, Seria A. 1, Szombathely, s. 255268.

Póczy K. 1969, Aquincum, Budapest.

Póczy K. 2003, Wasserver- und entsorgung, Gebäude des Staztzentrums, Forschungen in Aquincum. 1969-2002, Budapest, s. 144-149.

Radman-Livaja I. 2011, Le rôle des étiquettes de plomb dans le travail du textile à Siscia, [w:] C. Alfaro J.-P. Brun, Ph. Borgard, R. Pierobon Bemoit (red.), Textiles y Tintes en la ciudad Antigua. Actas del III Symposium Internacional sobre Textiles y Tintes del Mediterráneo en el mundo antiguo (Nápoles, 13 al 15 de noviembre, 2008), València, s. 181-196.

Radman-Livaja I. 2013, Craftspeople, Merchants or Clients? The Evidence of Personal Names on the Commercial Lead Tags from Siscia, [w:] M. Gleba, J. Pásztókai-Szeőke (red.), Making Textiles in Pre-Roman and Roman Times. People, Places, Identities, Oxford, s. 87-108.

Radaman-Livaja I. 2014, Olovne tesere iz Sisk (Plombs de Siscia), Zabreb.

Römer-Martijnse E. 1987, Ein beschrifteted Bleitäfelchen - Zeugnis handwerklicher Tätigkeit in Carnuntum?, Carnuntum Jahrbuch, s. 119-122.

Schlabow K. 1976, Textilfunde der Eisenzeit in Norddeutschland, Neumünster.

Schober A. 1923, Römischen Grabsteine von Noricum und Pannonien, Wiedeń.

Siciński A. 2002, Styl życia a kultura, Idem, Styl życia, kultura wybór. Szkice, Warszawa, s. 21-32.

Sommer M. 2012, Dress and Identity - A Social Psychologist's Perspective, [w:] H. Wiegand, A. Wieczorek, Kleidung und Identität in religiösen Kontexten der römischen Kaiserzeit, Regensburg, s. 258-263.

Stone S. 2001, The Toga: From National to Ceremonial Costume, [w:] J.L. Sebsta, L. Bonfante, The world of Roman Costume, Madison, s. 13-45.

Webster J. 2001, Creolizing the Roman Provinces. American Journal of Archaeology 105, s. 209-225.

Wild J.P. 1967, Soft-finished Textiles in Roman Britain, The Classical Quarterly 17, 1, s. 133-135.

Wild J.P. 1970, Textile Manufacture in the Northern Roman Provinces, Cambridge.

Wild J.P. 1988, Textiles in Archaeology, Aylesbury 1988.

Wilson A. 2003, The Archaeology of the Roman fullonica, Journal of Roman Archaeology 16, s. 442446.

Woolf G. 1996, Becoming Roman. The origins of Provincial Civilization in Gaul, Cambridge.

Zsidi P. 2006, Az Aquincum polgárváros. Vezető az Aquincumi Múzeum romkertjében, Budapest. 